\title{
Effect of Saline Water Irrigation on Chemical Properties and Fertility Status of Soil
}

\section{Imran Shehzad ${ }^{1}$, Ghulam Sarwar ${ }^{*}$, Muhammad Zeeshan Manzoor ${ }^{1}$, Ayesha Zafar', Sher Muhammad ${ }^{2}$ and Ghulam Murtaza ${ }^{1}$}

${ }^{1}$ Department of Soil and Environmental Sciences, College of Agriculture, University of Sargodha, Pakistan; ${ }^{2}$ Department of Agricultural Sciences, Allama Iqbal Open University, Islamabad, Pakistan

Abstract | Decline in agriculture production due to salinity is one of the key problems in many areas around the globe including Pakistan. Around the globe approximately, 800-million-hectare area is salt affected and it is estimated that up to middle of $21^{\text {st }}$ century, $50 \%$ of the arable land all over the world will be destroyed due to salinization problem. Use of canal water is the only strategy where saline and good quality waters are used in a cyclic manner for leaching down the salts that accumulated during irrigation with saline water. In this manner, salt accumulation does not rise beyond critical limit of the crop. The experiment consisted of 4 treatments replicated four times and randomized complete block design (RCBD) was used to make layout. Treatments were; T1 = canal water, T2 = water of EC $2.0 \mathrm{dS} \mathrm{m}{ }^{-1}, \mathrm{~T} 3=$ water of EC $3.0 \mathrm{dS} \mathrm{m} \mathrm{m}^{-1}$ and T4 = water of EC $4.0 \mathrm{dS} \mathrm{m}^{-1}$. Maize was sown as test crop. Pre and post-harvest soil analysis was carried out for different physical and chemical characteristics. Soil samples were collected from all the plots and analyzed for different chemical properties like EC, $\mathrm{pH}, \mathrm{SAR}, \mathrm{Cl}, \mathrm{CO}_{3}, \mathrm{HCO}_{3}, \mathrm{Ca}, \mathrm{Na}, \mathrm{Mg}, \mathrm{N}, \mathrm{P}$ and $\mathrm{K}$. Results of the experiment revealed that use of saline water irrigation impaired different chemical properties of the soil and also had negative impact on fertility status of the soil. All the collected data were subjected to statistical analysis.

Received | March 20, 2020; Accepted | April 30, 2020; Published | July 27, 2020

*Correspondence | Ghulam Sarwar, Department of Soil and Environmental Sciences, College of Agriculture, University of Sargodha, Pakistan; Email: ghulam.sarwar@uos.edu.pk

Citation | Shehzad, I., G. Sarwar, M.Z. Manzoor, A. Zafar, S. Muhammad and G. Murtaza. 2020. Effect of saline water irrigation on chemical properties and fertility status of soil. Pakistan Journal of Agricultural Research, 33(3): 527-534.

DOI | http://dx.doi.org/10.17582/journal.pjar/2020/33.3.527.534

Keywords | Brackish and canal water, Irrigation, Maize, Soil chemical properties and fertility status

\section{Introduction}

$\mathrm{M}$ aize (Zea mays L.) is highly cross-pollinated species and monoecious crop of Asia, and now a day considered poultry feed industry back bone. Maize is very nutritious fodder and it is the largest resource of livestock feed. Maize can be grown for fodder purpose in all over the Pakistan with extensive climatic range. It is be harvested after 8-10 weeks after sowing (Rashid and Iqbal, 2012). Maize is moderately salt sensitive crop (Maas et al., 1983). It also has significant role for the production of jelly glucose, flakes, energile, and custard in many industries. Now a days, corn is also used in the production of varnishes, ammunition, paints shortening compounds, soaps and many other products (Khan et al., 1999). Maize fodder contains $51.69 \%$ neutral detergent fiber, $40.18 \%$ fodder crude fiber, $28.797 \%$ fodder cellulose, $22.98 \%$ acid detergent fiber and maize seed grains contains 71.97 $\%$ starch in grain, $4.85 \%$ oil in grains, $9.74 \%$ protein in grains, and $9.44 \%$ crude fiber (Ali et al., 2014). Weed pervasion, excessive or sometimes no use of fertilizers and other factors are the main reasons due to which yield and growth of maize crop is affected (Khan et al., 2013). 
At present, global agriculture faces many problems, such as $70 \%$ more food production versus 2.3 billion additional people by 2050 . While fighting against hunger and poverty, more efficiently consuming rare natural resources and adapting to change of drastic climate (FAO, 2009). Because of various abiotic stresses low productivity in most cases is attributed. It has been expected that more than $50 \%$ of yield is decreased because of abiotic stresses and the salt stress is one of them (Rodríguez et al., 2005). Around the globe, salt stress is foremost concern for agriculture because it affects almost all the functions of the plant. Greater than $6 \%$ of the land in world and a third of the arable lands are severely under salt stress (FAO, 2008). Economy of Pakistan is based mainly on irrigated land of the country that is 17 million hectares in total and out of this, 6.3 million hectares is affected by salts. This salt-affected area has to be reclaimed to make the country prospers and developed (Qadir et al., 2000). The development of soil salinity is due to two main causes, one is the direct tide during the rainy season, and the second is the upward movement of saline groundwater during the dry season (Haque, 2006).

Salinity affects every plant at any growth and development stage but germination rate, seedling growth and percentage of germination affect in different ways according to plant species (Gul et al., 1999). High concentrations of salts affect seed germination, and the inability of water, causing ion to be disrupted, leading to osmotic stress and ion toxicity. The salinity causes osmotic stresses which are due to decrease of soil water potential. (Khan and Panda, 2008). It has been reported a decrease in biomass, changes in the capacity of photosynthesis in the water of foliated leaf potential leaves due to salinity. Reduction in the pigment content of the leaves is due to rise in levels of salts that increases the level of $\mathrm{Na}$ ${ }^{+}, \mathrm{Cl}^{-}$while decrease in level of $\mathrm{K}^{+}$and $\mathrm{Ca}^{2+}$ content are also results of salinity (Mansour et al., 2005). Consequently, installation of tube wells is growing day by day. Using unfit water poses problems of salt buildup in the rhizosphere. The increase of salinity in the root zone can be detrimental to the crops grown.

The management of soils affected by salt involves combination of various agricultural practices such as water quality, chemical modification and local conditions including climate, economic, cultural and political environment of crops and the existing agricultural system. Previously after lot of scientists compiled effective tools to alter and use of several modifications to improve the properties of saline soils which may be either physical or chemical. To reduce the problem of saltiness, there is no single procedures have been invented by scientist but many practices were utilized that performs adequately (Mashali, 1995). The significance of use of organic matter in this regard has been recognized due to its effect on the upgrading and altering the properties of saline soil for the growth of the crop, as well as due to its role as source of nutrients. Several organic amendments, such as compost and manure have been examined for their effectiveness in the recovery of saline soils. Use of organic amendments for reclamation of sandy soil is little alone but a big literature is available on its effectiveness to perk up the physical properties of soil (Sarwar, 2005).

The practice of domestic animal manure/dung has been recommended for a long time because of its value as nutrition for plants and as an alteration to the properties of the soil. The efficiency of the compost relies upon its composition, which differs according to the age and type of animal, consumption of feed and the management of waste. The application of organic matter was found or incorporated with surface soil to improve soil structure and increase the rate of water leakage. Thus, farm yard manure (FYM) applied can improve and conserve soil structure (Bhatnagar et al., 1992). Organic matter like manure or compost has capability to modify properties of clay and sandy soil. Use of farmyard manure, N, P and K for a long term improves hydraulic conductivity, total stability, water retention capacity and porosity of soil (Darwish et al., 1995). Singh et al. (1998) described that continuously adding farmyard manure to saline soil results in a reduction of soil $\mathrm{pH}$ and enhancement in carbon content along with exchange capacity of replaceable cations. Similarly, Gabir (1984) found that height of plant and dry yield of alfalfa plant improved significantly due to the use of organic materials, which improves the filtration of salt and reduces the sodicity. Chicken dung proved very effective in resisting the effect of salinity, which was reflected in the relative promotion of growth and yield in response to the amount applied.

\section{Materials and Methods}

Harmful effects of saline water were evaluated on soil chemical properties and fertility status after growing 
maize crop. This experiment was designed under randomized complete block design (RCBD) having 4 treatments which were replicated four times. For this purpose, plot of $4 \times 4 \mathrm{~m}^{2}$ size was used for each treatment.

$\mathrm{T}_{1}=$ canal water; $\mathrm{T}_{2}=$ water of $\mathrm{EC} 2.0 \mathrm{dS} \mathrm{m} \mathrm{m}^{-1} \mathrm{~T}_{3}=$ water of EC $3.0 \mathrm{dS} \mathrm{m}^{-1} ; \mathrm{T}_{4}=$ water of $\mathrm{EC} 4.0 \mathrm{dS} \mathrm{m} \mathrm{m}^{-1}$

The bed for sowing of maize seeds was prepared through cultivation of field for 2-3 times with tractormounted cultivar. Maize variety "Sargodha 2002" was sown using $37 \mathrm{~kg} \mathrm{ha}{ }^{-1}$ seed rate. For weeds free crop, twice hoeing practice was done to avoid competition between weeds and crop. Before irrigation, water of required range as mentioned in the treatment plan was prepared and then applied accordingly. Inorganic fertilizers \{urea, diammonium phosphate (DAP) and sulphate of potash (SOP)\} were applied @ 190-150$100 \mathrm{~kg}$ NPK per hectare respectively. At maturity, crop was harvested. The soil samples were collected at the depth of $0-15 \mathrm{~cm}$ with the help of soil auger. Soil samples were analyzed for $\mathrm{pH}_{\mathrm{s}}, \mathrm{SP}, \mathrm{EC}, \mathrm{Ca}^{2+}, \mathrm{Mg}^{2+}$, $\mathrm{Na}^{+}, \mathrm{K}^{+}, \mathrm{N}, \mathrm{P}, \mathrm{CO}_{3}{ }^{2-}, \mathrm{HCO}_{3}{ }^{-}, \mathrm{Cl}^{-}$and $\mathrm{SAR}$. Analytical methods of Handbook 60 of USDA (1969) were used for different determinations Table 1.

\section{Statistical analysis}

Statistical analyses of all the collected data were done using Tukey's test at five percent level of probability.

\section{Results and Discussion}

\section{Soil pH}

The $\mathrm{pH}$ level of the soil has an essential role in growing the plants. Soil $\mathrm{pH}$ mainly used to measure the acidity and alkalinity of soils. Data indicated that $\mathrm{pH}$ of soil differed significantly by the use of canal and saline water. Maximum pH (8.45) of soil was recorded in treatment $\mathrm{T}_{4}$ with water of $\mathrm{EC}=4 \mathrm{dSm}^{-1}$ (Figure 1 ). It was also obvious from the data that differences among various treatments were significant when seen through the yardstick of statistics. Data explained that EC= 3 and $\mathrm{EC}=2 \mathrm{dSm}^{-1}\left(\mathrm{~T}_{3}\right.$ and $\left.\mathrm{T}_{2}\right)$ produced 8.15 and 8.04 soil $\mathrm{pH}$ respectively. Minimum $\mathrm{pH}$ (7.92) was noted with the use of canal water $\left(\mathrm{T}_{1}\right)$. Statistically, treatment $\mathrm{T}_{3}$ and $\mathrm{T}_{2}$ (with water of $\mathrm{EC}=3$ and $\mathrm{EC}=$ $2 \mathrm{dSm}^{-1}$ ) were non-significant. However, treatment $\mathrm{T}_{4}$ and $\mathrm{T}_{3}$ were significant with results in term of statistics. However, according to Hossain et al. (2015) different levels of salinity had an impact on soil $\mathrm{pH}$.
Findings of Murtaza (2019) were also in the same directions who applied canal and saline water to grow sorghum crop. Similarly, results of Manzoor (2019) were also in the same direction who conducted a field experiment to grow sorghum crop applying canal and saline water.

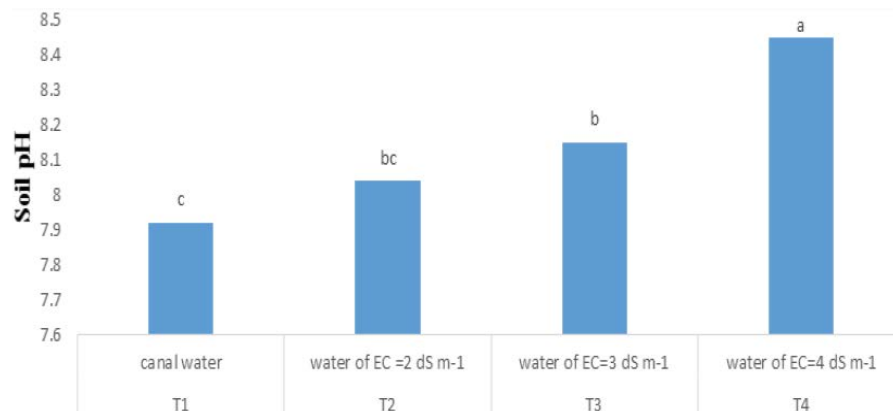

Figure 1: Effect of canal and saline water on $p H$ of soil.

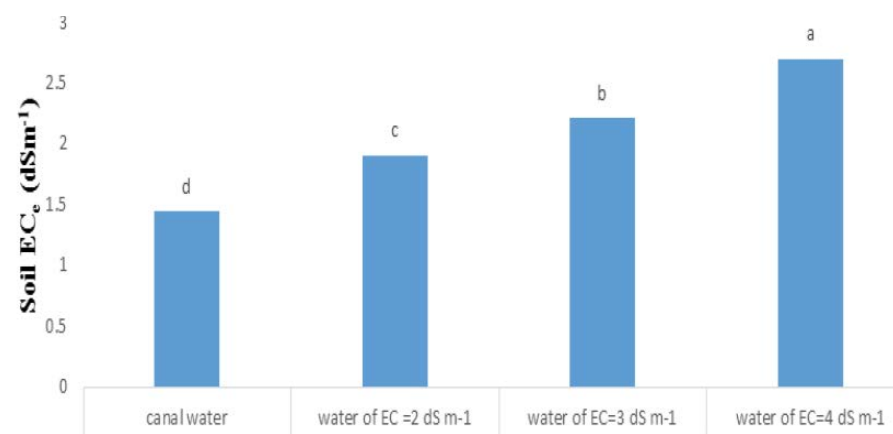

Figure 2: Effect of canal and saline water on $E C_{e}$ of soil.

\section{Soil EC $\left(d S m^{-1}\right)$}

Electrical conductivity (EC) is associated with soil characteristics that affects the productivity of crop, soil organic matter, subsoil properties, soil drainage capacity and texture, salinity and cation exchange ability. Data of this experiment showed that $\mathrm{EC}_{\mathrm{e}}$ of soil varied in all tested treatments. Considerable statistical differences among treatments regarding soil EC were observed (Figure 2). It was also obvious from the data that differences among various treatments were significant when seen through the yardstick of statistics. The highest $\mathrm{EC}\left(2.7 \mathrm{dSm}^{-1}\right)$ of soil was analyzed with water of $\mathrm{EC}=4 \mathrm{dSm}^{-1}\left(\mathrm{~T}_{4}\right)$. The determined value of soil $\mathrm{EC}$ for treatment $\mathrm{T}_{3}$ and $\mathrm{T}_{2}$ (water of $\mathrm{EC}=3 \mathrm{dSm}^{-1}$ and water of $\mathrm{EC}=2 \mathrm{dSm}^{-1}$ ) were 2.21 and $1.9 \mathrm{dSm}^{-1}$ respectively. However, the lowest value of soil EC $\left(1.44 \mathrm{dSm}^{-1}\right)$ was measured where irrigation of canal water was used $\left(\mathrm{T}_{1}\right)$. Tedeschi and Aquila (2005) and Malik et al. (2015) also reported that soil EC was also enhanced by using saline water. Findings of Murtaza (2019) were also in the same directions who applied canal and saline water to grow sorghum crop. Similarly, results of 
Manzoor (2019) were also in the same direction who conducted a field experiment to grow sorghum crop applying canal and saline water.

\section{Soil SAR}

Sodium adsorption ration (SAR) is the water quality trait that is used in the management of sodiumaffected soils. This is numerically derived property which is based on the concentration of different cations like sodium, calcium and magnesium. Data showed irrigating with canal and saline water had impact on soil SAR. All the treatments differences to SAR of soil were significant when adjudged through the yardstick of statistics (Figure 3). The irrigation with water of $\mathrm{EC}=4 \mathrm{dSm}^{-1}\left(\mathrm{~T}_{4}\right)$ recorded maximum SAR (14.4) of soil (Figure 3). In the same way, $\mathrm{T}_{3}$ (continuous irrigation with water of EC 3.0 $\mathrm{dS} \mathrm{m} \mathrm{m}^{-1}$ ) and $\mathrm{T}_{2}$ (continuous irrigation with water of EC $2.0 \mathrm{dS} \mathrm{m}^{-1}$ ) produced 12.15 and 9.95 values of soil SAR respectively. The application of canal water $\left(\mathrm{T}_{1}\right)$ recorded the lowest SAR (7.6) of soil. Results indicated that among all treatments, irrigation with canal water is performed well as compared to all other treatments. Malik et al. (2015), also recognized our results who revealed that saline water reduced the SAR of soil. Findings of Murtaza (2019) were also in the same directions who applied canal and saline water to grow sorghum crop. Similarly, results of Manzoor (2019) were also in the same direction who conducted a field experiment to grow sorghum crop applying canal and saline water.

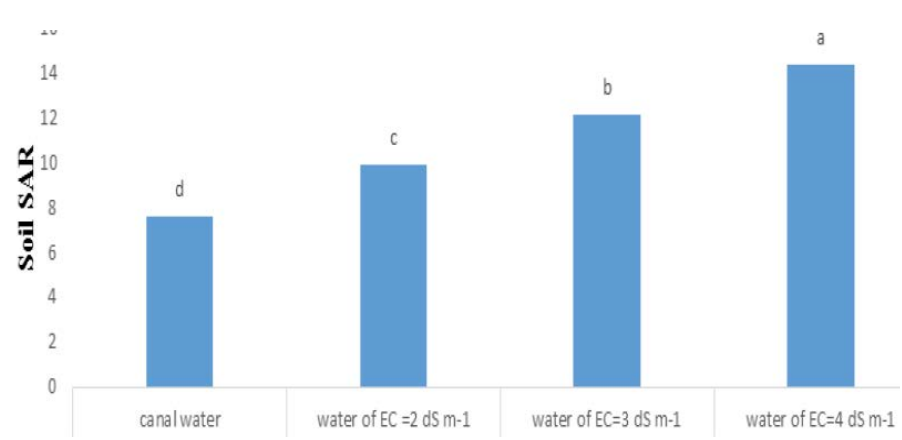

Figure 3: Effect of canal and saline water on SAR of soil.

\section{Organic matter (\%) of soil}

Growth of plants is positively affected by usage of organic matter because organic matter plays significant direct impact on characteristics of soil like physical and biological and chemical characteristics. Understanding the role of organic matter in maintaining a healthy soil is essential for developing ecologically sound agricultural practices. Organic matter (\%) of soil was significantly affected by use of brackish water. It was also obvious from the data that differences among various treatments were significant when seen through the yardstick of statistics. Data regarding organic matter (\%) of soil was presented in Figure 4 which indicated that irrigation with canal water $\left(\mathrm{T}_{1}\right)$ recoded maximum organic matter $(0.92 \%)$ of soil. Among all the treatments, canal water showed superiority over all others treatments. The irrigation with water of $\mathrm{EC}=2$ and $\mathrm{EC}=3 \mathrm{dSm}^{-1}\left(\mathrm{~T}_{2}\right.$ and $\left.\mathrm{T}_{3}\right)$ produced 0.86 and $0.80 \%$ of organic matter in soil. These both treatments were significant with each other statistically. Minimum organic matter (0.73\%) of soil was analyzed with water of $\mathrm{EC}=4 \mathrm{dSm}^{-1}\left(\mathrm{~T}_{4}\right)$. Hossain et al. (2015) supported our findings who described that salinity significantly affected the soil organic matter (\%) and reduction in soilorganic matter with rise in salt level. Malik et al. (2015) indicated that use of brackish water irrigation significantly reduced the organic matter (\%) in soil. Findings of Murtaza (2019) were also in the same directions who applied canal and saline water to grow sorghum crop. Similarly, results of Manzoor (2019) were also in the same direction who conducted a field experiment to grow sorghum crop applying canal and saline water.

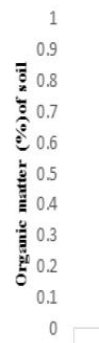

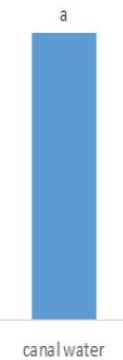

T1

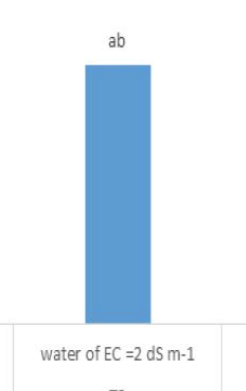

$\mathrm{T} 2$

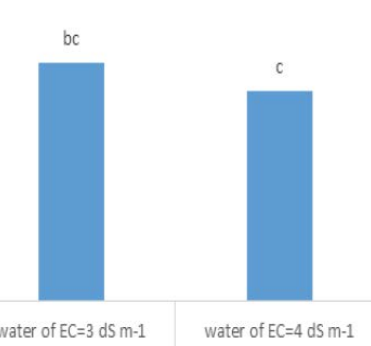

$\mathrm{T} 4$
Figure 4: Effect of canal and saline water on organic matter of soil.

\section{Phosphorous (ppm) of soil}

Phosphorus is an important macro-element, required for plant nutrition. It participates in photosynthesis, transfer of energy and synthesis and breakdown of carbohydrates. Data depicted that application of canal and brackish water had a significant effect on the phosphorous contents of soil. Data presented in Figure 5 indicated that application of canal water was better than irrigation with water of $\mathrm{EC}=2,3$ and $4 \mathrm{dSm}^{-}$ ${ }^{1}$. It was also obvious from the data that differences among various treatments were significant when seen through the yardstick of statistics. The maximum concentration of phosphorous $(7.70 \mathrm{ppm})$ of soil was measured where irrigation with canal water $\left(T_{1}\right)$ was applied. Data also showed that irrigation with water of $\mathrm{EC}=2 \mathrm{dSm}^{-1}\left(\mathrm{~T}_{2}\right)$ recorded phosphorous contents 
$6.95 \mathrm{ppm}$ of soil. Application with water having $\mathrm{EC}=$ $3 \mathrm{dSm}^{-1}$ and $\mathrm{EC}=4 \mathrm{dSm}^{-1}\left(\mathrm{~T}_{3}\right.$ and $\left.\mathrm{T}_{4}\right)$ produced 6.40 and 6.15 ppm phosphorous concentration respectively. However, these both treatments (water of $\mathrm{EC}=3$ $\mathrm{dSm}^{-1}$ and water of $\mathrm{EC}=4 \mathrm{dSm}^{-1}$ ) were statistically non-significant. Our findings were also supported by Malik et al. (2015) and they said that brackish water caused reduction in phosphorous contents of the soil. Similar to our results the Hossain et al. (2015) reported that phosphorous contents in soil decreased significantly by using saline water. Findings of Murtaza (2019) were also in the same directions who applied canal and saline water to grow sorghum crop. Similarly, results of Manzoor (2019) were also in the same direction who conducted a field experiment to grow sorghum crop applying canal and saline water.

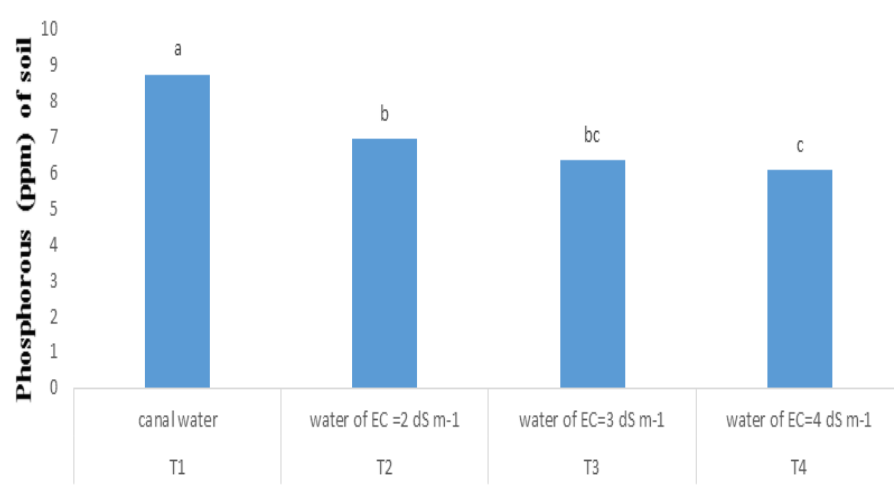

Figure 5: Effect of canal and saline water on phosphorus of soil.

\section{Potassium (meg/L) of soil}

Potassium levels in soil were significantly affected by use of canal and brackish water. Data regarding potassium contents of soil was presented in Figure 6 which showed that irrigation with canal water $\left(T_{1}\right)$ recoded maximum potassium contents $(2.40 \mathrm{meq} / \mathrm{L})$ of soil. Among all treatments, canal water showed superiority over all other treatments. It was also obvious from data that differences among various treatments were significant when seen through the yardstick of statistics. The irrigation with water of $\mathrm{EC}=2$ and $\mathrm{EC}=3 \mathrm{dSm}^{-1}\left(\mathrm{~T}_{2}\right.$ and $\left.\mathrm{T}_{3}\right)$ produced 2.10 and $1.90 \mathrm{meq} / \mathrm{L}$ of potassium contents of soil respectively. However, $T_{2}$ and $T_{3}$ were statistically non-significant. The minimum potassium contents $(1.60 \mathrm{meq} / \mathrm{L})$ of soil was obtained with water of $\mathrm{EC}=4 \mathrm{dSm}^{-1}\left(\mathrm{~T}_{4}\right)$. Another researcher Hossain et al. (2015) also reported similar findings as our results revealing that increasing the salts, potassium contents was reduced. Findings of Murtaza (2019) were also in the same directions who applied canal and saline water to grow sorghum crop. Similarly, results of Zeeshan (2019) were also in the same direction who conducted a field experiment to grow sorghum crop applying canal and saline water.

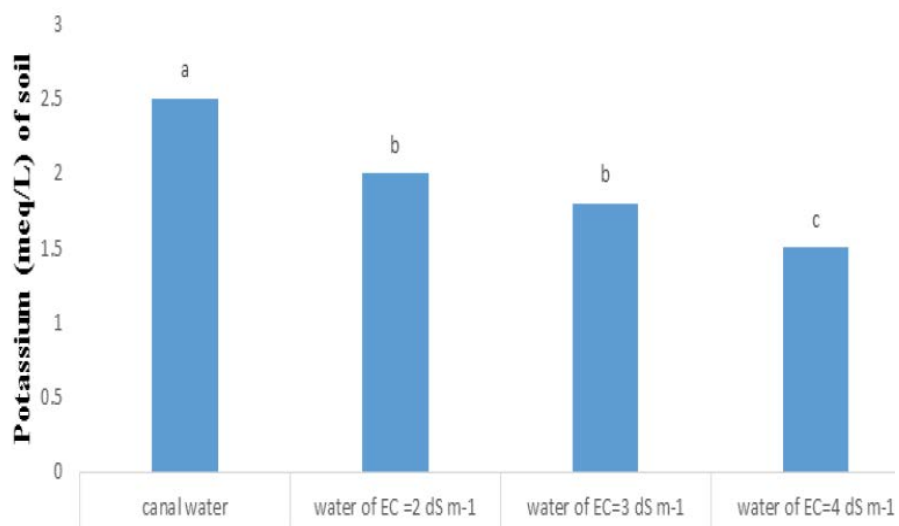

Figure 6: Effect of canal and saline water on potassium of soil.

Table 1: Analysis of experimental soil before cultivation.

$\begin{array}{lll}\text { Parameters } & \text { Unit } & \text { Value } \\ \mathrm{pH}_{\mathrm{s}} & - & 8.3 \\ \mathrm{EC}_{\mathrm{e}} & \mathrm{dSm}^{-1} & 0.73 \\ \text { Carbonates } & \text { Milli equivalent per liter } & 1.5 \\ \text { Bicarbonates } & \text { Milli equivalent per liter } & 3.12 \\ \text { Chloride } & \text { Milli equivalent per liter } & 2.95 \\ \text { Sulfate } & \text { Milli equivalent per liter } & 1.47 \\ \text { Calcium+Magnesium } & \text { Milli equivalent per liter } & 2.92 \\ \text { Sodium } & \text { Milli equivalent per liter } & 3.65 \\ \text { SAR } & - & 3.02 \\ \text { Organic matter } & \text { \% } & 0.81 \\ \text { P } & \text { ppm } & 6.8 \\ \text { K } & \text { ppm } & 109.8 \\ \text { Soil textural class } & - & \text { Clay loam }\end{array}$

\section{Soil cations $\left(\mathrm{Na}^{+}\right.$and $\left.\mathrm{Ca}^{2+}+\mathrm{Mg}^{2+}\right)$}

Sodium concentration in soil responds significantly to application of canal and saline water. Among all the treatments, irrigation with canal water found better as compared to others. It was also obvious from the data that differences among various treatments were significant when seen through yardstick of statistics (Table 2). Sodium concentration of soil increased with increase in EC of irrigation water. The highest sodium $(17.28 \mathrm{meq} / \mathrm{L})$ of soil was observed with water of $\mathrm{EC}=4 \mathrm{dSm}^{-1}$ (4.9). However, irrigation with water of $\mathrm{EC}=3\left(\mathrm{~T}_{3}\right)$ and $\mathrm{EC}=2 \mathrm{dSm}^{-1}\left(\mathrm{~T}_{2}\right)$ recorded 14.76 and $12.23 \mathrm{meq} / \mathrm{L}$ sodium in soil respectively and these treatments were noted as statistically significant. The minimum sodium $(9.55 \mathrm{meq} / \mathrm{L})$ of soil was obtained where irrigation with canal water $\left(\mathrm{T}_{1}\right)$ was applied. 
Table 2: Effect of canal and saline water on concentration of cations and anions in soil.

\begin{tabular}{|c|c|c|c|c|c|c|}
\hline \multirow[t]{2}{*}{ Treatments } & \multicolumn{2}{|c|}{$\begin{array}{l}\text { Cations (milli } \\
\text { equivalent per liter) }\end{array}$} & \multicolumn{4}{|c|}{$\begin{array}{l}\text { Anions (milli equivalent per } \\
\text { liter) }\end{array}$} \\
\hline & $\begin{array}{l}\text { Sodi- } \\
\text { um }\end{array}$ & $\begin{array}{l}\text { Calcium + } \\
\text { Magnesium }\end{array}$ & $\begin{array}{l}\text { Car- } \\
\text { bonates }\end{array}$ & $\begin{array}{l}\text { Bicar- } \\
\text { bonates }\end{array}$ & $\begin{array}{l}\text { Chlo- } \\
\text { ride }\end{array}$ & $\begin{array}{l}\text { Sul- } \\
\text { fate }\end{array}$ \\
\hline $\begin{array}{l}\mathrm{T} 1=\text { canal } \\
\text { water }\end{array}$ & 9.55 & 3.16 & 1.50 & 3.00 & 8.45 & 1.45 \\
\hline $\begin{array}{l}\mathrm{T} 2=\text { water of } \\
\text { EC } 2.0 \mathrm{dS} \mathrm{m}^{-1}\end{array}$ & 12.23 & 3.05 & 1.57 & 3.30 & 12.43 & 1.70 \\
\hline $\begin{array}{l}\text { T3 = water of } \\
\text { EC } 3.0 \mathrm{dS} \mathrm{m}^{-1}\end{array}$ & 14.76 & 2.95 & 2.30 & 3.83 & 14.17 & 1.80 \\
\hline $\begin{array}{l}\text { T4 = water of } \\
\text { EC } 4.0 \mathrm{dS} \mathrm{m}^{-1}\end{array}$ & 17.28 & 2.88 & 2.55 & 4.15 & 18.10 & 2.20 \\
\hline
\end{tabular}

Calcium and magnesium play critical role in nutrition as well as in cell wall deposition. Its helps to maintain chemical balance in the soil, reduces soil salinity, and improves water penetration. The highest $\mathrm{Ca}+\mathrm{Mg}$ concentration $(3.16 \mathrm{meq} / \mathrm{L})$ of soil was obtained where irrigation with canal water $\left(\mathrm{T}_{1}\right)$ was applied (Table 2). It was also obvious from the data that differences among various treatments were significant when seen through the yardstick of statistics. The other treatments $\left(\mathrm{T}_{2}\right.$ and $\left.\mathrm{T}_{3}\right)$, irrigation with water of $\mathrm{EC}=2 \mathrm{dSm}^{-1}$ and water of $\mathrm{EC}=3 \mathrm{dSm}^{-1}$ proved nonsignificant in term of statistics. The water of $\mathrm{EC}=2$ $\mathrm{dSm}^{-1}$ and water of $\mathrm{EC}=3 \mathrm{dSm}^{-1}$ noted $\mathrm{Ca}+\mathrm{Mg}$ concentration of soil 3.05 and $2.95 \mathrm{meq} / \mathrm{L}$ respectively. However, among all treatments, the lowest $\mathrm{Ca}+\mathrm{Mg}$ concentration $(2.88 \mathrm{meq} / \mathrm{L})$ of soil was obtained from $\mathrm{T}_{4}$ (irrigated with water of $\mathrm{EC}=4 \mathrm{dSm}^{-1}$ ).

\section{Soil anions $\left(\mathrm{CO}_{3}{ }^{2-}, \mathrm{HCO}_{3}{ }^{1-}, \mathrm{Cl}^{-}\right.$and $\left.\mathrm{SO}_{4}{ }^{2-}\right)$}

Data indicated that carbonates concentration of soil significantly influenced by using water of saline nature. The maximum carbonates concentration $(2.55 \mathrm{meq} / \mathrm{L})$ of soil was gained in the treatment $\left(\mathrm{T}_{4}\right)$ grown with water of $\mathrm{EC}=4 \mathrm{dSm}^{-1}$ (Table 2). In the same way carbonates of soil $2.3 \mathrm{meq} / \mathrm{L}$ was noted with water of $\mathrm{EC}=3 \mathrm{dSm}^{-1}\left(\mathrm{~T}_{3}\right)$. Application of irrigation water of $\mathrm{EC}=2 \mathrm{dSm}^{-1}$ and canal water $\left(\mathrm{T}_{2}\right.$ and $\left.\mathrm{T}_{1}\right)$ produced carbonates concentration of soil 1.57 and $1.501 \mathrm{meq} / \mathrm{L}$ respectively. Statistically, both these treatments $\left(\mathrm{T}_{2}\right.$ and $\left.\mathrm{T}_{1}\right)$ water of $\mathrm{EC}=2 \mathrm{dSm}-$ 1 and canal water proved non-significant with each other. It was also obvious from data that differences among various treatments were significant when seen through the yardstick of statistics.

Data indicated that bicarbonates of soil differed significantly by the use of canal and saline water. It was also obvious from the data that differences among various treatments were significant when seen through the yardstick of statistics. The maximum value of bicarbonates $(4.15 \mathrm{meq} / \mathrm{L})$ of soil was recorded with treatment $\mathrm{T}_{4}$; water of $\mathrm{EC}=4 \mathrm{dSm}^{-1}$ (Table 2). The $\mathrm{EC}=3 \mathrm{dSm}^{-1}\left(\mathrm{~T}_{3}\right)$ recorded bicarbonates $3.83 \mathrm{meq} / \mathrm{L}$ of soil. Data also showed that irrigation with water of $\mathrm{EC}=2$ and canal water $\left(\mathrm{T}_{2}\right.$ and $\left.\mathrm{T}_{1}\right)$ produced 3.3 and $3.0 \mathrm{meq} / \mathrm{L}$ bicarbonates of soil respectively. However, two treatments (canal water, water of $\mathrm{EC}=2 \mathrm{dSm}$ $\left.{ }^{1}\right)$ were statistically non-significant. Findings showed that irrigation with canal water was more effective than water of $\mathrm{EC}=2,3$ and $4 \mathrm{dSm}^{-1}$.

Data depicted that irrigating with canal and brackish water has pronounced impact on soil chlorides. Differences among treatments with respect to chloride were significant statistically (Table 2). The irrigation with $\mathrm{EC}=4 \mathrm{dSm}^{-1}\left(\mathrm{~T}_{4}\right)$ recorded maximum concentration of chlorides $(16.22 \mathrm{meq} / \mathrm{L})$ of soil. It was also obvious from the data that differences among various treatments were significant when seen through the yardstick of statistics. In the same way, irrigation with water of $\mathrm{EC}=3 \mathrm{dSm}^{-1}$ and $\mathrm{EC}=2 \mathrm{dSm}^{-1}\left(\mathrm{~T}_{3}\right.$ and $\mathrm{T}_{2}$ ) produced 12.77 and $10.37 \mathrm{meq} / \mathrm{L}$ of chlorides in soil respectively. The application of canal water recorded the lowest chlorides (7.90) of soil. Results indicated that among all treatments, irrigation with canal water is performed well as compared to other treatments.

Sulfates concentration in soil responds significantly by using canal and brackish water. Among all the treatments, irrigation with canal water $\left(\mathrm{T}_{1}\right)$ found better as compared to others. It was also obvious from the data that differences among various treatments were significant when seen through the yardstick of statistics. The sulfate concentration in soil increases with enhancement in EC of irrigating water. The greatest sulfate $(2.45 \mathrm{meq} / \mathrm{L})$ of soil was observed with water of $\mathrm{EC}=4 \mathrm{dSm}^{-1}$ (4.14). The irrigation with water of $\mathrm{EC}=3$ and $\mathrm{EC}=2 \mathrm{dSm}^{-1}\left(\mathrm{~T}_{3}\right.$ and $\left.\mathrm{T}_{2}\right)$ recorded 2.10 and $1.80 \mathrm{meq} / \mathrm{L}$ sulfate in soil respectively, and these treatments were statistically significant. The minimum sulfate $(1.50 \mathrm{meq} / \mathrm{L})$ of soil was obtained where irrigation with canal water was applied (Table 2).

Ragab et al. (2008) also supported our findings and exposed that soil carbonates and bicarbonates increase with increase in salinity levels from 0.43 (control), $4.85,6.60$ and $8.86 \mathrm{dSm}^{-1}$. The work of the previous 
researchers Tedeschi and Aquila (2005) also favored these outcomes that $\mathrm{Cl}^{-}$in brackish water elevated chloride concentration in soil enhanced significantly. Similarly, Hassanein et al. (1993) who revealed that elevated salt concentration of irrigation water enhanced concentration of carbonates. Findings of Murtaza (2019) were also in the same directions who applied canal and saline water to grow sorghum crop. He concluded an increase in the concentration of different cations like $\mathrm{Na}^{+}$and anions like $\mathrm{CO}_{3}{ }^{2-}$, $\mathrm{HCO}_{3}{ }^{1-}$ and $\mathrm{Cl}^{1-}$ with the use of saline water as source of irrigation. Similarly, results of Manzoor (2019) were also in the same direction who conducted a field experiment to grow sorghum crop applying canal and saline water. He also noted that application of saline water enhanced the concentration of sodium, carbonate, bicarbonate and chloride in the soil but that of calcium + magnesium was lowered.

\section{Conclusions and Recommendations}

It is concluded from this study that brackish/ saline water irrigation impart significant impact on chemical properties of soil by increasing values of $\mathrm{pH}, \mathrm{EC}$ and SAR. Furthermore, concentration of $\mathrm{Na}^{+}, \mathrm{CO}_{3}{ }^{2-}, \mathrm{HCO}_{3}{ }^{1-}$ and $\mathrm{Cl}^{1-}$ was also enhanced when saline water was used as source of irrigation. On the other hand, application of canal water proved the best treatment to lower all these values in favorable and desired range.

\section{Author's Contribution}

Imran Shehzad: Conception and design of research work, conduction of experiment and write up.

Ghulam Sarwar: Academic Supervisor and guided throughout the research tenure.

Muhammad Zeeshan Manzoor: Member of research group and helped in laboratory analysis.

Ayesha Zafar: Member of research group and helped in laboratory analysis.

Sher Muhammad: Contributed in statistical analysis and manuscript write up.

Ghulam Murtaza: Memeber of research group and helped in data collection.

Conflict of interest

The authors have declared no conflict of interest.

\section{References}

Ali,Y.,Z.Aslam,M.Y.Ashraf, and G.R.Tahir.2014. Effect of salinity on chlorophyll concentration, leaf area, yield and yield components of rice genotypes grown under saline environment. Int. J. Environ. Sci. Technol., 1(3): 221-225. https://doi.org/10.1007/BF03325836

Bhatnagar, V.K., S. Kundu, and V. Prakash. 1992. Effect of long-term manuring and fertilization on soil-physical properties under soybean (Glycine max) wheat (Triticum aestivum) cropping sequence. Indian J. Agric. Sci., 62(3): 212-214.

Darwish, O.H., N. Persaud, and D.C. Martens. 1995. Effect of long-term application of animal manure on physical properties of three soils. Plant Soil. 176(2): 289-295. https://doi. org/10.1007/BF00011793

FAO. 2008. Land and plant nutrition management service. http://www.fao.org/ag/ag1/ag11/. Accessed on November/ 15/2012.

FAO. 2009. High level expert forum- how to feed the world in 2050, Economic and social development department, food and agricultural organization of the United Nations, Rome, Italy.

Gabir, A.M., 1984. The effect of irrigation frequencies and some soil amendments on Lucerne (Medicago sativa L.) grown in a salinesodic clay soil South of Khartoum area. M.Sc. (Agric) thesis, Univ. Khartoum.

Gul, B. and D.J. Weber. 1999. Effect of salinity, light, and temperature on germination in Allenrolfea occidentalis. Can. J. Bot., 77(2): 240246. https://doi.org/10.1139/b98-204

Haque, S.A., 2006. Review article; Salinity problems and crop production in coastal regions of Bangladesh. Pak. J. Bot., 38(5): 1359-1365.

Hassanein, S.A., N.F. Kandil, M.A. Abu-Sinna, and M.I. Selem. 1993. Effect of irrigation with Bahr El-Baqar drain water on some soil chemical properties and yield. Commun. Sci. Dev. Res., pp. 41.

Hossain, N., M. Muhibbullah, K.M.B. Ali, and M.H. Molla. 2015. Relationship between Soil Salinity and Physico-chemical Properties of Paddy Field Soils of Jhilwanja Union, Cox's Bazar, Bangladesh. J. Agric. Sci., 7(10): 166180. https://doi.org/10.5539/jas.v7n10p166

Khan, M.A., S. Kakar, K.B. Marwat, and I.A. 
Khan. 2013. Differential response of (Zea mays L.) in relation to weed control and different macronutrient combinations. Sains Malays., 42(10): 1395-1401.

Khan, M.H. and S.K. Panda. 2008. Alterations in root lipid peroxidation and antioxidative responses in two rice cultivars under $\mathrm{NaCl}-$ salinity stress. Acta Physiol. Plant., 30: 89-91. https://doi.org/10.1007/s11738-007-0093-7

Khan. M.A., N.U. Khan, K. Ahmad, M.S. Baloch and M. Sadiq. 1999. Yield of maize hybrid -3335 as affected by NP levels. Pak. J. Biol. Sci., 2(3): 857-859. https://doi.org/10.3923/ pjbs.1999.857.859

Maas, E.V. and G.J. Hoffman. 1977. Crop salt tolerance, current assessment. J. Irrig. Grain Div. 103(2): 115-134.

Malik, M.A., S.M. Nadeem, M. Ibrahim and S. Hussain. 2015. Effective use of brackish water for improving soil properties and chickpea (Cicerarietinum L.) growth through organic amendments. Soil Environ. 34(1): 65-74.

Mansour, M.M.F., K.H.A. Salama, F.Z.M. Ali and A.F.A. Hadid. 2005. Cell and plant responses to $\mathrm{NaCl}$ stress in Zea mays L. cultivars differing in salt tolerance. Gen. Appl. Plant Physiol. 31: 29-41.

Manzoor, M.Z., 2019. Leaching Fraction; an efficient soil management strategy for the use of brackish water in sorghum (Sorghum bicolor). MSc (Hons)/M Phil. Soil Science thesis, Dep. Soil Environ. Sci. Coll. Agric., Univ. Sargodha.

Mashali, A.M., 1995. Integrated soil management for sustainable use of salt-affected soils and network activities. Proceedings of the international workshop on integrated soil management for sustainable use of salt-affected soils. 6-10 November 1995. Bureau Soils Water Manage., Manila, Philippines. pp. 55-75.

Mass, E.V., G.J. Hoffman, G.D. Chaba, J.A. Poss, and M.C. Shannon. 1983. Salt sensitivity of corn at various growth stages. Irrig. Sci. 4: 4557. https://doi.org/10.1007/BF00285556

Murtaza, G., 2019. Organic matter: a tool for mitigating deleterious effects of saline water for the growth of sorghum (Sorghum bicolor). MSc (Hons)/M Phil. Soil Sci. thesis, Dep. Soil Environ. Sci., Coll. Agric., Univ. Sargodha.

Qadir, M., A. Ghafoor and G. Murtaza. 2000. Amelioration strategies for saline soils: a review. Land Degrad. Dev., 11(6): 501-521. https://doi.org/10.1002/1099$145 \mathrm{X}(200011 / 12) 11: 6<501:$ :A I D $\mathrm{LDR} 405>3.0 . \mathrm{CO} ; 2-\mathrm{S}$

Ragab, A.A.M., F.A. Hellal, and M.A. El-Hady. 2008. Water salinity impacts on some soil properties and nutrients uptake by wheat plants in sandy and calcareous soil. Aust. J. Basic Appl. Sci., 2(2): 225-233.

Rashid,M. and M.Iqbal.2012.Effect of phosphorus fertilizer on the yield and quality of maize ( $Z e a$ mays L) fodder on clay loam soil. J. Anim. Plant Sci, 22(1): 199-203.

Rodríguez, D., P.C. Martín, H. Jordán, F. Alfonso, A.M. Vera, and L. Sarduy. 2005. Effect of three supplements on the productive performance of bulls fed sugarcane forage. Cuban J. Agric. Sci., 39(1): 29-32.

Rodriguez, M.E., E. Canales, and O.H. Borras. 2005. Molecular aspects of abiotic stress in plants. Biotechnol. Apl., 22(1): 1-10.

Sarwar, G.,2005. Use of compost for crop production in Pakistan. Ökologie und UmweltsicherungUniversität Kassel, Germany.Ph.D.Dissertation Singh, A.K., L.P. Amgain, and S.S. Singh. 1998. Integrated nutrient management in rice-wheat system under midland situation. In Ex-tended Summaries of $21^{\text {st }}$ Int. Cong. Agron. Held New Delhi. pp. 450-451.

Tedeschi, A. and R.D. Aquila. 2005. Effects of irrigation with saline waters, at different concentrations, on soil physical and chemical characteristics. Agric. Water Manage., 77: 308-322. https://doi.org/10.1016/j. agwat.2004.09.036

U. S. Salinity Laboratory Staff. 1969. Diagnosis and Improvements of saline and alkali soils. Handbook No. 60. USDA. U.S. Govt. Printing Office, Washington, DC, USA. 